\title{
LITERATURE AND IDENTITY
}

\section{Dragana Litričin Dunić1}

\author{
Scinetific review
}

\author{
Faculty of Teacher Training, Educons University, The Republic of Serbia
}

Received: 24.03.2015

UDC: 82.091

\begin{abstract}
Literature can represent, on the one hand, the establishment of cultural and national identity, and, on the other hand, a constant indicator of the differences. Self-image and the image of the Other in literature is very important not only for understanding national character and preservation of cultural identity, but also for the release from ideological reading and stereotyping. Analyzing the image of the Other, research into the representation of the Balkans symbolically represents in the popular literature of the West, study of the cultural context and the processes that formed the writer's perceptions that determine the establishment of stereotypes about Homo Balcanicus and many others, are all important tasks of imagological research, as well as the key research tasks conducted nowadays. In this paper we shall discuss some of these issues in the field of comparative literature.
\end{abstract}

Key words: comparative literature, imagology, identity, anthropology, literary criticism, Other.

\section{INTRODUCTION}

Literary works may affect the imaginary boundaries to become real, and the actual boundaries to move... Imagology is a branch of comparative literature that examines the study of the Other in literature, as well as the impact of such images in our reception of literary phenomena. It emerged in the middle of the last century "as a special area of the French comparatistics school which specializes in the research literature 'image' (ie. image or 'stereotypes') on 'another country' ', and more recently it also includes the so-called autoimaginative creation, that is, production of representation of themselves and their own community ..." (Brajović, 2007, p. 15). French comparatist Daniel-Henry Pageaux in the late eighties pointed out that one of the main tasks of imagology was "cultural mediation " (Pageaux, 1994, p- 40).

Italian comparatist Armando Gnisci optimistically points out that comparatistics transformed into "knowledge of the encounter" with a strong ethical dimension of these encounters in which "each participant's own traditions remain active, as well as cultural history, languages and poetics" (Gnisci, 1999, p. 7 ). When it comes to the Serbian comparatist works in the domain of this area, great attention has been devoted to this topic by Zoran Konstantinović. In the book Intertextual comparatistics (2002) he stresses that by interpreting this "key", the change of our mentality can be seen.

Konstantinović found the explanation of the importance of comparative imagology in the article "Comparative Imagology of the Balkans and Central European space" in which he writes about a wide range of imagology because it speaks not only about the image of another nation, but also about "how peoples' see themselves, what is peculiar to them ..." (Konstantinović, 2006, p. 3). The narrative, image, prejudices and stereotypes are key analytical tools that enable the creation of ideological constructions of reality that can be studied through imagological interpretation of literary texts and in an interdisciplinary approach and connection with: history, anthropology, psychology... Self-image and image of the Other in literature is very important not only for understanding the national character and the preservation of cultural identity, but also for the release from ideological reading and stereotyping.

\footnotetext{
Correspodence to:

Dragana Litričin Dunić,PhD, Educons University, Faculty of Teacher Training

Sremska Kamenica, The Republic of Serbia

E-mail:ddunic@gmail com
} 
Analyzing the image of the Other, research into the representation of the Balkans symbolically represents in the popular literature of the West, study of the cultural context and the processes that formed the writer's perceptions that determine the establishment of stereotypes about Homo Balcanicus and many others, is an important task of imagological research, as well as the key research tasks nowadays. Zoran Milutinovic in his book Encounter in the Third Place, in the chapter "Culture and Identity after the empire - the challenge of comparative literature," examines how today's comparative literature refers to the canon. (Milutinovic, 2006, pp. 21-82 ). The emergence of postcolonial studies has brought new perspectives on comparitistics. Literature can be, on one hand, the establishment of cultural and national identity, and on the other hand, a constant indicator of the differences.

\section{OBSERVATIONS}

\section{Key questions}

The book Orientalism by Edward Said presented before the comparatistics an important ethical question: whether it is writing about other cultures and their literatures value-neutral or influenced by the political power of culture to which the author belongs? His key question is: "How do we represent another culture? What is another culture?" (Said, 1978. p. 325). Said noted that the study of the Other was a privilege of the West and by these mentioned interpretations the Orient was actually constructed (Said, 2008. p. 431). Such an interpretation of the Other through stereotypes and generalizations takes place, in fact, as long as the inferior and Other accepts the imposed images of themselves as their own views. Under the influence of Said's emerged other studies on other regions of the world, for example Maria Todorova's book Imaginary Balkans, which deals with constructing the Eastern Europe.

It is quite clear that, some long formed images of the Balkans became some kind of stereotypes, and as such can, through symbolization, producing images of the Balkan Otherness, a kind of mapping, indicate a narrative conquest of the Balkans and the imaginary colonization.

\section{Balkanization and Homo Balcanicus}

In imagological context, the image has a wide receptive and informative power, and handles a range of related terms, such as misconceptions, prejudices, stereotypes, myths, mentality, otherness, and Balkanic terms: Balkanization, Balkan model of the world, the Balkan mentality...

In this context, the Balkans is used as a metaphor as of the early 20th century, it received a clear pejorative connotations, and eventually became a symbol for something halfway-developed, semi-civilized, semioriental, aggressive, barbaric...

Such metaphor was criticized by Maria Todorova in the book Imagining the Balkans (2006, pp. 93-100), claiming that the specific discourse that is called Balkanism essentially determines attitudes towards the Balkans, but also concrete actions towards them. She also notes the interesting concept of "Balkanization" - that is derived from the word Balkan. The word Balkanization entered the vocabulary of journalists and politicians as a synonym for something backward, problematic ... So, the term Balkanization completely separated from the Balkans and the paradigm is associated with a variety of problems. In many modern dictionaries and encyclopedias the same anachronistic mistake is made.

In literature, the repertoire of stereotypes, as we know, is not just fun, but also teaching, it is the first step in reading literary meeting of different cultures, it is a provocative speech on intercultural communication.

For example, the travelogue genre ranged between reality and fantasy, and often is regarded as superficial entertainment. Rare are those who are in these seemingly easy genre of foreigners visitors, recognized something more than a book intended for the general public. Historians and anthropologists also in the itineraries sensed reflections and influence of politics of countries from which the traveler comes.

The British and American travel writing from the nineteenth century interpreted representations of the Balkans as the Other in the area of Europe, as orientalized "strange foreigner". The Balkans became Orient Europe, but while Western literature for the Orient and the associated common places like "eroticism", "splendor", "mysticism"; image "East European" are not the same, although there are similarities. The Balkans are often seen as a "primitive", "stagnant", "inferior". 
(The period between the two world wars was marked by a trend of writing imaginary travelogues like novels of Agatha Christie, while those adventurous or political character were rarer. The imaginary travelogues this area is conceived as a space ruled by violence, mystery, espionage, robbery and assassination.) Of course, when it comes to ideological interpretations the arguments that are immanently literary are taken into account. Thus, as we read in an interesting book Stories of Narcissus the Abuser: Abuse and Literature, "as a side effect of ideological readings, enshrines the abuse literature, which takes place in the so-called literary life, with the help of the means underlying the literary and private life." (Ahmetagić, 2011, p. 186). "Cultural identity is a process that directly faces the need for universalization of individual cultures and necessity of respect of all special features. This process is to establish key cultural values and at the same time denying their hierarchy. Search for cultural identity becomes cryptographic culture, while confirmation of a distinctive identity requires communication with each other. "(Koković, 2005, p. 298).

Considering a literary text as a reflection of cultural identity which can be seen in mentality structure and level of civilization of a people, one of the most famous Serbian literary critics, the second half of the 20th century, a prominent "Andricologist" Petar Džadžić in 1987 wrote a book Homo Balcanicus, Homo Heroicus. In the new edition of his literary and anthropological studies in 1994 Džadžić added another book.

Homo Balcanicus, Homo Heroicus illuminates the dark features of the Balkan mentality. In the clash of the elements of comedy and identity drama, the literary critic, through his anthropological vision, tried to break the traditional taboos in our society through the interpretation of oral and written literature. In these studies he showed a great interest in some kind of imagological criticism - although imagology was then a relatively new field that Džadžić did not mention in his works.

In these books, the critic is the closest to what today means autoimaginative creation, that is, the production of a play about themselves and their own community. He wrote a kind of mentality studies. Through the eyes of literary texts Džadžić analyzed the creation and expression of national identity. The most interesting interpretations refer to the myth mystification in our historical, literary, cultural and social conditions. The criting, following the footsteps of the scientist Jo- van Cvijić, analyzed the Balkan "collective shadow", accompanied by features such as vanity, narcissism, over-ambitiousness and vindictiveness. Character analysis points to the dinar impetuosity, self-congratulation, vanity, destruction ... as well as the tendency of a person from Balkan region to perceive people and phenomena as "extreme opposites."

The eminent Nobel Prize winner Ivo Andric wrote, among others, about the impulsive man from the Balkans. In Sings Near the Travel Road he asks the question: "Why can't Balkan countries enter the circle of enlightened world, even through their best and most talented representatives?" Some of the reasons Andric stated are: "the absence of respect for the man, his full dignity and inner freedom" as well as "the mess, violence, injustice caused by vengeful thoughts." In these words we find the explanation of critical, polemical and any other form of action in this area.

\section{CONCLUSION}

The phenomena and trends in literature significantly affect and define cultural identity, and thanks to imagology as a discipline that combines literary criticism, anthropology, ethnopsychology, sociology, psychology, and postcolonial criticism which now directs imagological theoretical research we can consider the aforementioned significant phenomena.

Maria Todorova indicates that the inhabitants of the Balkans have "a self-negative perception because it comes from outside as so unfavorable and full of contempt" (Todorova, 2006, p. 106) and strongly opposes the so-called category of the national character.

She believes that the Balkans are an inseparable part of Europe, but culturally constructed as "internal otherness", and served to "absorb a multitude of externalized political, ideological and cultural frustrations stemming from tensions and contradictions inherent in the regions and societies outside the Balkans." (Todorova, 2006, p. 355)

From Said's perspective, literature is important because it affects society and cultural identity while at the same time may reflect the influence of political and cultural domination. Interpretation of the Other through some kind of generalizations and stereotypes takes place, in fact, as long as inferior and the Other does not accept the imposed image of themselves as their own identity. In short, literature has a political role according to the long-term professor of comparative literature at the prestigious Columbia University. 
Commitment to imagological interpretation that covers literature in its relationship with the ideology, in a way that does not invalidate its aesthetic autonomy, undertakes to introduce the concept of images, perceptions, stereotypes, prejudices... Between the authors and the Other cultural background and personal feelings mediate. Due to the action of subjectivity, imagology does not reveal what indeed members of a group are, but as this group shows itself, so these studies have been located in the field of metadiscourse.

In the book Comparative Literature by the French authors Claude Pichois and Andre M. Rousseau (1973, p. 89) we read that the misconceptions are faster and better communicated than the truth. When you create an image of the Other, it inevitably reflects the one who creates. Image of the Other so often appears as a negation of the Other. The result of postcolonial criticism that exceeds its particularity is that it is clearly indicated that "ignoring the development of sociocultural specificities of different literature lead to erroneous generalizations" (Valdés, 1992, p. 5).

Cultural studies as a recent academic discipline are crucial for great changes in the interpretation of literature, in addition to the rise of postcolonial studies. Finally, the media and popular culture play a decisive role in shaping the identity and it is one of the main tasks of cultural studies as an academic discipline to describe the current phenomena and processes.

\section{REFERENCES}

Andrić, I. (2005). Znakovi pored puta. Beograd: Politika. Ahmetagić, J. (2011). Priče o Narcisu zlostavljaču:zlostavljanje $i$ književnost. Beograd: Službeni glasnik.

Brajović, T. (2007). Identično različito.Beograd: Geopoetika. Džadžić, P. (1995). Homo balcanicus, homo heroicus I. Sabrana dela. VIII.Beograd: Zavod za udžbenike i nastavna sredstva. Džadžić, P. (1995). Homo balcanicus, homo heroicus II. Sabrana dela. IX. Beograd: Zavod za udžbenike i nastavna sredstva. Gnisci, A. (1999). Komparativna književnost kao disciplina dekolonizacije. Književna istorija.XXXI.5-12.

Koković, D. (2005). Pukotine kulture. Novi Sad: Prometej. Konstantinović, Z. ( 2002). Intertekstualna komparatistika: komparatistički prilog proučavanju srpske književnosti. Beograd: Narodna knjiga Alfa.

Konstantinović, Z. ( 2005). Komparativna imagologija balkanskog i srednjoevropskog prostora. Slika Drugog u balkanskim i srednjoevropskim književnostima. Beograd: Institut za književnost i umetnost.

Milutinović,Z. (2006).Susret na trećem mestu. Beograd: Geopoetika.

Pageax, D. (1994). La litteratture genérale et comparé. Paris: Armand Colin

Pishois, Cl.,Rousseau A.M. (1973).Komparativna književnost. Zagreb: Matica Hrvatska.

Said, E. (1978). Orientalism. New York: Pantheon.

Said, E. (2008). Orijentalizam. Beograd: XX vek.

Todorova, M. ( 2006). Imaginarni Balkan. Beograd: Biblioteka 20. vek.

Valdés, M. (1992). Comparative Literary History as Discourse. In Honor of Anna Balakian. Bern: Peter Lang. 